\author{
スラブ型 $\mathrm{CO}_{2}$ レーザーを用いた小片分割加工法の \\ 芸術的プラスチック加工 \\ 櫻田 典世，石井 良夫，久保田 譲，渡辺一弘 \\ 創価大学大学院 工学研究科情報システム学専攻（†192-8577 東京都八王子市丹木町1-236）

\section{Artistic Plastic-Material Processing by a Segmented Pixel Drawing Method Using a Slab $\mathrm{CO}_{2}$ Laser}

\author{
Noriyo SAKURADA, Yoshio ISHII, Yuzuru KUBOTA, and Kazuhiro WATANABE \\ Department of Information Systems Science, Faculty of Engineering, Soka University, \\ 1-236, Tangi-cho, Hachioji, Tokyo 192-8577
}

(Received April 12, 2002)

\begin{abstract}
A segmented pixel drawing method has been developed in order to create a tasteful artistic work for plastic materials. With this method, various artistic tastes were successfully realized on transparent plastics by combinations of visual effects and tones using a slab $\mathrm{CO}_{2}$ laser which was operated in a segmented pixel-base scheme. A relationship of the system controlling parameters with the visual effects and tones has been quantitatively analyzed in terms of 3-visual effects and 8-tones which have been experimentally obtained. Tasteful artistic works have been interestingly printed on acrylic materials from digital images. Discussions on the evaluation for the printing effects and the detailed system configuration are given from the viewpoint of a viable laser sculpture system.
\end{abstract}

Key Words: Segmented pixel drawing method, Slab RF excited $\mathrm{CO}_{2}$ laser, Artistic laser processing

1.はじめに

$\mathrm{CO}_{2}$ レーザーによる加工は，鋼板等の各種材料の切断を 中心に，溶接や表面改質へ応用されており，その加工機 は電気・機械, 電子・半導体, 自動車, 鉄鋼などさまざ まな産業分野に導入され，製造ラインあるいは製造シス テムにおいて多用されている1-4)。特に最近では，ハイ ピークパルス $\mathrm{CO}_{2}$ レーザーによる高密度実装プリント回路 基板の微小穴あけ加工技術が開発され，実用化が進んで いる5). 他方，このような工業的加工分野とは対照的に， レーザー加工は，芸術的加工物の制作にも応用されてい る.この芸術的加工分野では, 従来のマーキング法やマ スキング法に加え, 写真などの画像データのグレース ケール階調をレーザー照射点の粗密によって材料表面に 表現加工を行なう方法や，ビームをクリスタルなどの加 工対象内部に集光することにより多光子吸収やフォトリ フラクティブ効果6) を利用して中空加工を行なう方法など が実用化されている7,8)。このような材料表面に画像を描 画する従来の方法は，レーザーによる精密穴加工を行な う技術9)を応用し，元画像をより忠実に，いわば写実的に 加工対象物に描写することを目的としている。

筆者らはこれまでに, 従来法のように画像の階調を忠 実に表現し, 高解像度の画像表現加工を行なうだけでな
く，視覚効果を利用し，プラスチック材料を対象として 芸術的 “趣” も表現可能な小片分割加工法一Segmented Pixel Drawing法(SPD法)を提案してきた10,11)。実際のさまざま な芸術作品においても, 千差万別な大きさがあり, 精密 さを追求した作品もあれば，風合や趣を重視した作品も あり，多種多様な表現方法が存在している。

本論文では，SPD法をもちいたプラスチック加工物にお ける芸術的加工の一手法を確立するために, スラブ型 $\mathrm{CO}_{2}$ レーザーによるSPD加工システムを構築し, 制御パラメー 夕と階調・視覚効果との関係を定量的に明らかにした。 実験では，8階調・3視覚効果を実現し本加工法の特長を 検討した。また，デジタル画像を元に，芸術的“趣”を有す る芸術的加工物の制作を試みた。

\section{SPD法}

\section{1 階調と視覚効果}

従来の芸術的加工法とは異なるSPD法における特長は, 元画像と加工対象面をそれぞれ小片単位に分割し, 解 析・加工を行なうことによって，元画像の質感をプラス チック加工材料表面に視覚効果として表現しょうとする 点にある。実際に画像の一画素から滑らかさなどの質感 を判断する事は不可能であるため, このSPD法では, 画像 
中のいくつかの隣接画素を一単位として小片に分割し解 析することによって元画像の質感を判断する. また, 単 一ドットのレーザー照射だけでは加工時に質感や階調を 表現することは困難であるため, 加工対象も小片に分割 し，その小片ごとにレーザー照射のドット配置，密度， パルス幅や繰り返し周波数といった制御パラメータをさ まざまに変化させて加工を行なうのである。このように ドット単位ではなく小片単位にて画像解析・レーザー加 工を行なうことによって, 加工における表現力を豊かに し, 視覚効果の表現だけでなく階調表現も行なうことが できる。

一般的な視覚効果による表現法の一例として, 漫画を 描く技法におけるスクリーントーンを挙げることができ る。これは, 点や線などのさまざまなテクスチャパター ンが印刷された紙を小片に切り抜き, 表現したい絵の上 に貼り付ける技法である。このさまざまなテクスチャパ ターンの有する視覚効果によって, 描画の質感, さらに 色の濃淡を表現することが可能である。この技法では, 特に点の集合パターンが多く使われており, 点の大きさ や密度によってさまざまな種類のパターンが用意されて いる.SPD法もこのスクリーントーンを用いたさまざまな 画質表現と類似していると考えることができ, 加工パ ターンを小片ごとに変化させることによって, さまざま な質感や階調表現が可能となる。

SPD法は加工対象を小片に分割し, その小片内に特長的 なドット配置を行なうことを基本としている. 表現可能 な階調は一義的には, 小片内のドット加工占有面積に依 存するため, ドット照射時のドットの大きさと密度に よって決定される。また, 小片内を同一占有面積にて加 工を行なう場合でも，照射するドット密度の違いによっ て視覚効果に変化が生じるため, さまざまな表現が可能 となる，例えば，小片内を $3 \times 3$ ドットの正方配列にて加 工した場合と, 各ドットの面積をその3/4倍とし, ドット 数を $4 \times 4$ ドットの正方配列にした場合では, 小片内の加 工占有面積が同じであるため階調は同一に表現される が, 視覚的には異なって見える。このような視覚的差異 を視覚効果としてレーザー加工における芸術的表現に有 効利用することがSPD法における最大の特長である.

\section{2 元画像とSPD加工データ}

元画像から加工データ作成までの流れをFig. 1に示す. 初めにCCDカメラやスキャナなど画像入力装置によって コンピュータに加工データの元となる画像を取り込む. その画像はデジタル画像として画素(ピクセル)分割により 構成されるため, 本加工法において必要な各小片に対応 した加工データを作成することは, 主に他の加工法にお いて用いられているマーキング法やマスキング法などと 比べ容易である。次に，このデジタル画像を各ピクセル の輝度值情報のみを持つRAWデータ形式に変換する。こ のデータ形式に変換することにより，比較的単純なアル ゴリズムによって画像解析が可能となる。このRAWデー 夕形式の元画像について, 正方状に隣接する数ピクセル を小片単位にグループ化し, 小片内の全ピクセルについ

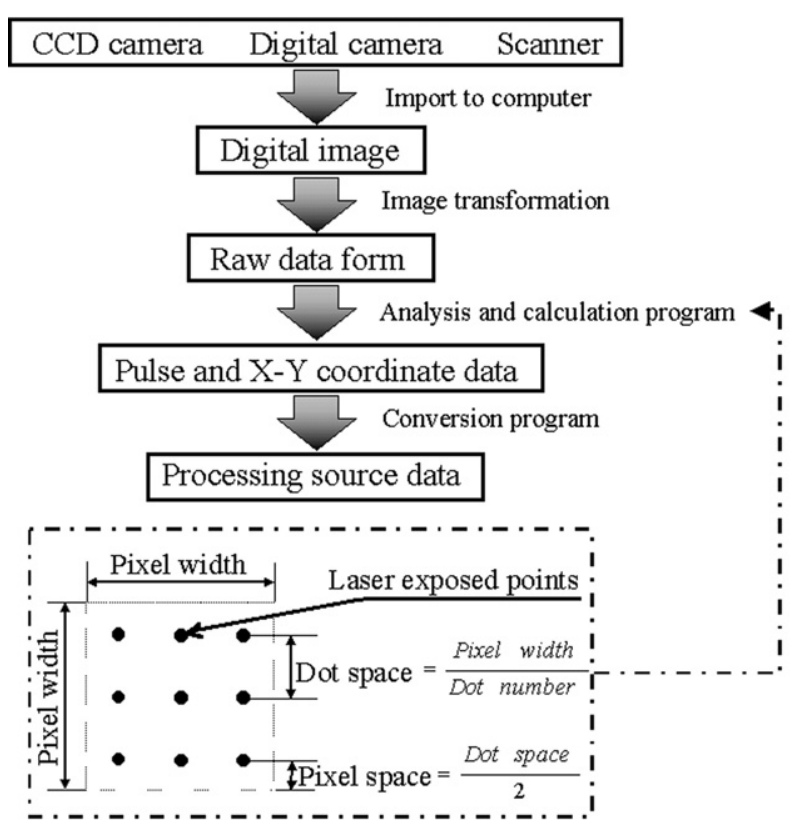

Fig. 1 Procedure of making a processing source data from a captured digital image together with laser dot configuration in a given pixel size for the processing source data.

て明度を反映する平均輝度值に対して加工小片の階調 を, 画像の滑らかさや粗雑さといった質感を反映する輝 度值のばらつきに対して視覚効果をそれぞれ対応させる よう画像解析ならびに加工デー夕の算出を行なう。これ により，レーザーをドット照射するX-Y座標位置とレー ザーのパルス幅や繰り返し周波数を決定し，これらの情 報を有するデータファイルを作成する。ここで算出され る小片内のレーザー照射を行なうドット位置と小片の大 きさの関係は, 図中下部に示すとおり, 任意の小片幅に 対し，その幅をドット数にて等分した幅が各ドットの間

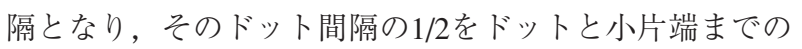
間隔として決定される。ドット照射点と小片端に間隔を 設けることにより，小片整列時に隣接小片同士の重複を 防ぎ，小片間の境界線を目立たなくすることができる。 最後に，算出されたデータファイルをスキャニングコン トローラによって制御可能な加工データ形式に変換す る. 以上の手順によって一般的な画像から加工デー夕の 作成を行なう。

\subsection{SPD加工システム}

Fig. 2にSPD法における加工システムの構成図を示す。 ここで用いるレーザーは, 筆者らが開発した最大平均出 力 $200 \mathrm{~W}$ の高周波励起スラブ型 $\mathrm{CO}_{2}$ レーザーである。この レーザーは，「小型軽量でありながら加工に十分な出力を 有する」,「情報機器によるビームの制御性が高い」,「ビー ム品質がよい」といった特長を有する ${ }^{12)}$. 本実験では, 平 均出力を $50 \mathrm{~W}$ とし, 繰り返し周波数を $0.5 \sim 4 \mathrm{kHz}$, デュー ティー比を10〜90\%に制御することによってドット照射 時におけるパルス幅の制御を行なった。加工作業に先立 ち, 本研究室にて考案した紫外線CCDカメラを用いた レーザービームプロファイラ13,14)によりレーザーのビー 


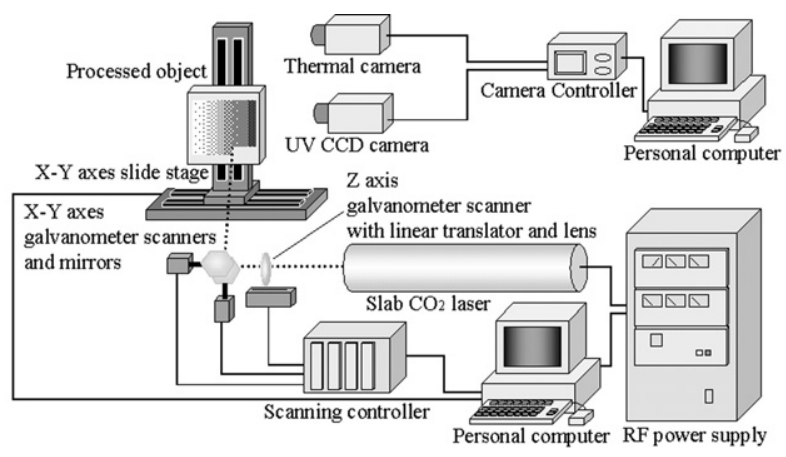

Fig. 2 Experimental configuration of the SPD laser processing system with a slab RF excited $\mathrm{CO}_{2}$ laser.

ム品質を確認し, さらに加工中の対象物についてサーモ カメラにより熱解析15,16)を行なうことによって，レーザー 本体ならびに加工制御機の微調整を行ない, 加工精度 · 再現性を確保した。加工制御系は, 高周波電源とGeneral Scanning社製のX-Y-Z軸ガルバノメータから構成されてお り，スキャニングコントローラを介してパーソナルコン ピュータによって制御される. 高周波電源は, 周波数 100 $\mathrm{MHz}$, 最高出力 $2 \mathrm{~kW}$ あ゙あり, スキャニングコントローラ から送られるレーザーのパルス幅と繰り返し周波数の情 報を持ったTTL信号によってレーザー本体へ印可する電力 の制御を行なった。本レーザーは印可される電力によ り, スラブ電極間の放電状態が変化し, レーザー出力レ ベルおよびON-OFF動作を制御することが可能である. 光 学制御系では, Z軸レンズならびにX-Y軸ミラーを, 前述 のガルバノメータにより駆動し，さらにZ軸レンズは，リ ニヤトランスレータを組み合わせる事により, 回転運動 から直線運動への変換を行ない駆動させた. Z軸レンズに よって加工点におけるビーム径や焦点位置の制御を, X-Y
軸ミラーによって加工平面における照射位置の制御を行 なった.レーザービームは複数のレンズとミラーから構 成される光学系ならびに光学制御系を通過し加工対象物 へ走査・照射される．X-Yスキャナによって加工対象面上 にレーザーを走査できる範囲は, 約 $8 \times 8 \mathrm{~cm}^{2}$ 以内に限ら れており，より大きな加工物を制作するためにX-Yスライ ドステージ(スライド幅 $200 \mathrm{~mm}$ )を用いた。これにより， 加工対象物をX-Y方向に移動させ, 約 $20 \times 20 \mathrm{~cm}^{2}$ の加工物 を制作することが可能である.

\section{3. 加工実験結果と検討}

加工材料として $\mathrm{CO}_{2}$ レーザーに対する吸収率の高い透明 アクリル部材を用い, 加工結果の背景を暗色とし, 制御 パラメータに対する小片の階調と視覚効果をそれぞれ評 価した。透明アクリル部材上のレーザー照射点は，レー ザーアブレーションにより白濁した照射痕を形成し透明 度が低下するため，背面を暗色することによってレー ザー非照射部との明度差が視覚的差異を生み出すことに なり, より良い評価が可能となる.アクリル部材の加工 されるエネルギ閾值を超えるエネルギが照射された部分 のみ照射痕が形成されるため，ガウス分布を有するレー ザービームのエネルギ強度分布によって，レーザーパ ワーと照射時間を制御することにより，照射痕の大きさ を変化させることが可能である，照射痕の大きさは，Z軸 レンズによりビーム径を制御することによっても変化さ せることができるが，ビーム径を大きくすることにより 照射痕の輪郭がぼやけてしまうため, 本実験では前者の 方法を採用した。

Fig. 3に制御パラメータの違いによる異なった階調と視 覚効果をもった加工実験結果を示す．Fig. 3 (a) はデータ
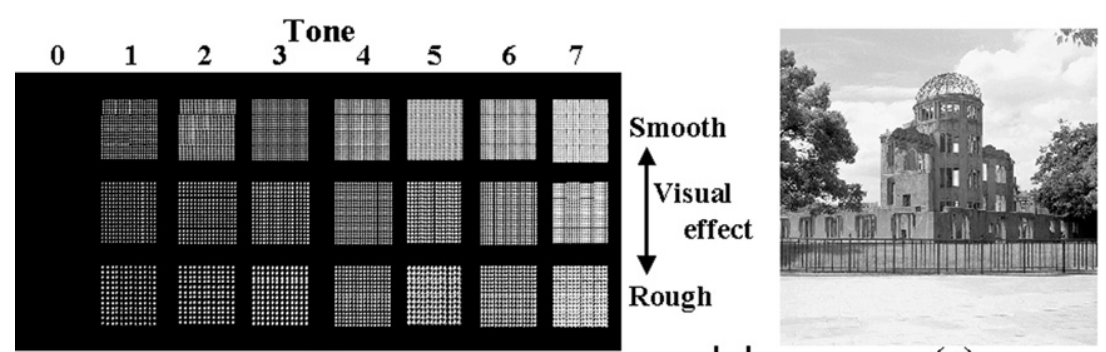

(a)

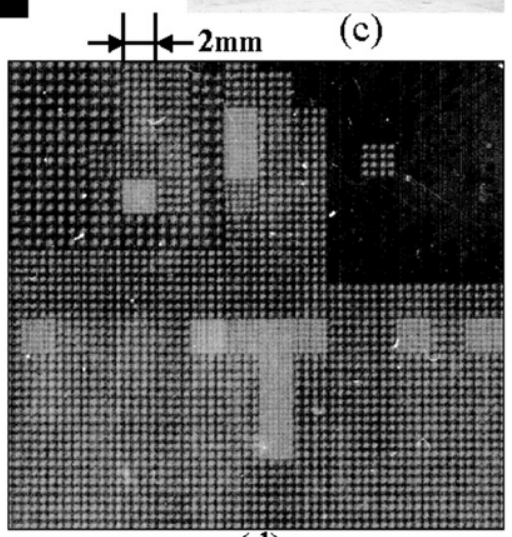

(b)

(d)

Fig. 3 A SPD pallet (a) of 8-tones and 3-visual effects for the printed example of a dome (b) based on an original picture (c) and an enlarged picture of the dotted square region in (b). 
ベースとして作成した各種小片のパレット，(b)はSPD加 工実験結果，(c) は元画像，(d) は (b)内の点線範囲の拡大 図である. 小片パレット (a) は, レーザードット照射の配 置, 密度, パルス幅や繰り返し周波数といった制御パラ メータのさまざまな組み合わせにより作成された約 200 個 の小片群より, 階調表現と視覚効果表現に適した小片の みを選択し列挙したものである。各小片の大きさは $2 \times 2$ $\mathrm{mm}^{2}$ であり, 図中の小片パレットは, 各小片を16個正方配 列したものである。左右で階調 (Tone) の変化, 上下で視 覚効果 (Visual effect)の変化を示す. 階調は小片内におけ る加工占有面積の違いによって表現され, 左側が暗階調 (黒)で右側に向かって順に明階調(白)になるよう整列して いる. 加工による階調は図に示すとおり7段階あり, 無加 工部分を最暗階調として, 合計8階調を作成した。本実験 では，小片面積 $2 \times 2 \mathrm{~mm}^{2}$ 内に重複せずに加工可能な最大 ドット数が約 80 ドット程度であるため, 各階調の視覚的 差異を顕著に表現するために8階調としたが, 小片サイズ を大きくすることにより，より多くの階調が作成可能で あると考えられる. 他方, 視覚効果は加工照射点数の違 いによって表現され，粗密の3段階を作成し，上段のドッ 卜数の多い方が滑らかな, 下段の少ない方が粗い視覚効 果を有している。制御パラメータの例として，第1階調の

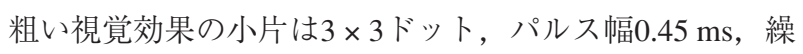
り返し周波数 $2 \mathrm{kHz}$ にてレーザー制御を行ない, その 1 ドッ

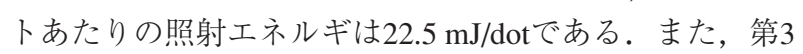
階調の粗い視覚効果の小片では, 1 ドットあたりの照射エ ネルギが $45.0 \mathrm{~mJ} / \mathrm{dot}$ であり，照射エネルギの制御によって ドットの加工面積が大きくなるよう制御した．SPD加工 実験結果 $(\mathrm{b})$ は画像 $(\mathrm{c})$ を元に, $2 \times 2 \mathrm{~mm}^{2}$ の小片を $100 \times 100$ 個配列し制作したもので, 全体の大きさは $20 \times 20 \mathrm{~cm}^{2}$ で ある. 手前の地面や建物といった人工的な部分と, 空の 雲や木といった自然対象の部分では, 同一階調による加 工でも異なる視覚効果にて加工を行なっているため微妙 な違いを表現できている，拡大図 (d)を見ると，階調なら びに視覚効果がドット照射の集合によって表現されてい ることがわかる。この加工では, 加工対象の範囲がX-Yス キャナミラーの走査範囲よりも大きいため加工対象を 16 分割しX-Yステージを用いて移動させ加工を行なったため に, ステージ座標平面とスキャナ座標平面の直交度なら びに正方度の微妙な誤差により分割部分に境界が見られ る.

Fig. 4に小片サイズを $1 \times 1 \mathrm{~mm}^{2}$ として，5階調による加 工実験結果を示す. 加工実験結果の大きさは, X-Yステー ジによる移動の必要がない $5.6 \times 5.6 \mathrm{~cm}^{2}$ である. 小片サイ ズを小さくすることによって, 小片内の加工可能な最大 ドット数が減少するために, 表現可能な階調数が減少し てしまうが，比較的きめ細かい加工が可能になる。サッ カーボールのように濃淡がはっきりとし, 形状の単純な 素材の表現に対しても, 十分な表現力を有していること がわかる。

前述までのSPD法では小片内のドット照射位置を正方配 列状に配置して行なっていたが，Fig. 5に乱数を用いて ドット配置を行なった加工実験結果を示す。階調はピク

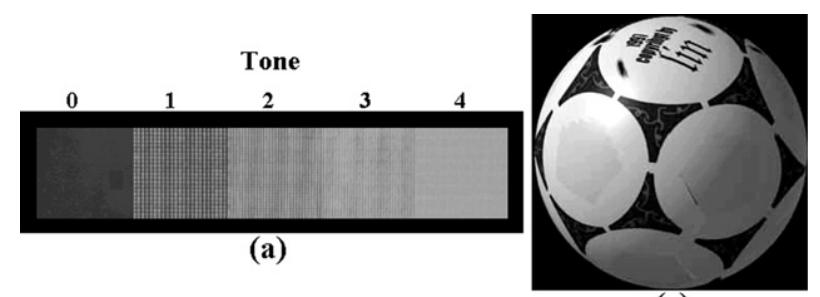

(c)

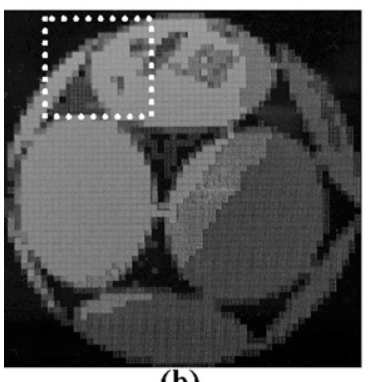

(b)

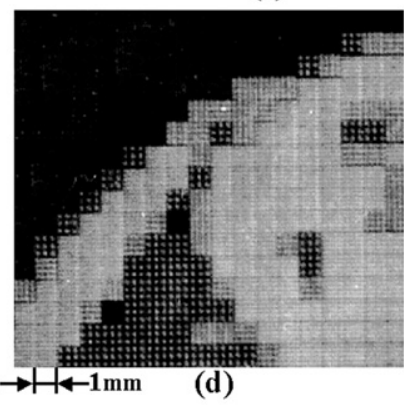

(d)
Fig. 4 A SPD pallet(a) of 5-tones for a soccer ball example (b) based on an original picture (c) with an enlarged picture(d) for the dotted square region in (b).

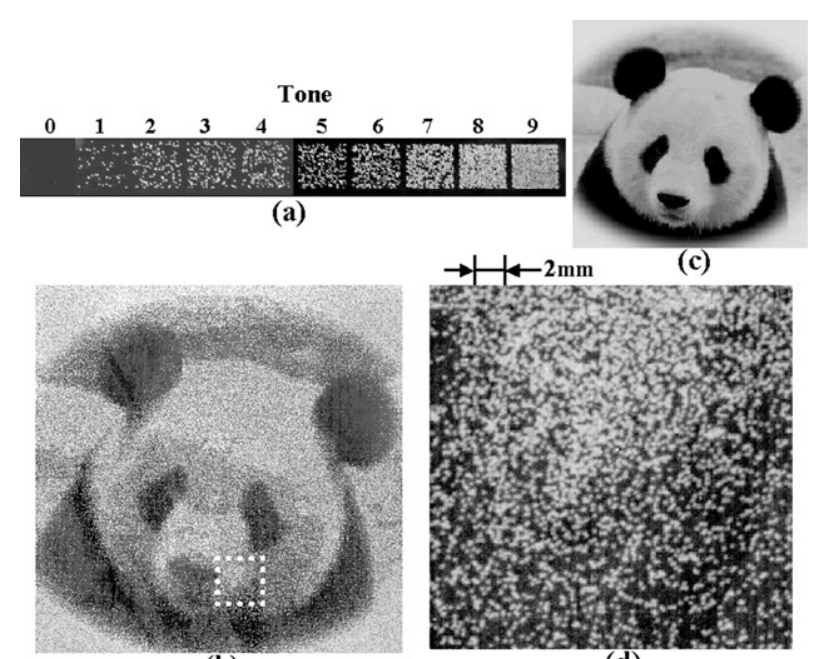

(b)

(d)

Fig. 5 A SPD pallet (a) of 9-tones with a random dots arrangement for a panda example (b) based on an original picture (c), and (d) an enlarged picture of the dotted square region in (b).

セル内の平均ドット密度によって表現され，ここでは平 均ドット密度を階調に応じて対数関数的に決定してい る。これは, 人の目の明度に対する視覚感度が, 絶対的 な明度值よりはむしろ明度レベルの比率に対して高いこ とをふまえ，ドット密度を階調に対し等間隔にではなく 対数関数的に変化させた. Fig. 5 では, 小片サイズを $2 \times 2$ $\mathrm{mm}^{2}$ とし, 階調を9階調作成した. 加工実験結果の大きさ は20 × $20 \mathrm{~cm}^{2}$ である。加工実験結果を見ると，前述まで のSPD法とは異なった，滑らかで自然な風合の点描画のよ うな視覚効果を得ることができた。

SPD法を応用し, 同一点にドット照射を繰り返すことに よって深さを有する加工物を作成することも可能であ る.この場合, 深さが主に照射回数に依存するため, 深 さの容易な制御が可能である。ドット照射によって深さ 
を出すため, 加工表面が白濁してしまうが, 白濁面にZ軸 を駆動したディフォーカスビームを照射することによっ て透明度を上げ，透明に加工された面に，ささら を行ない, さまざまな視覚効果を表現する。このよう に, SPD法をさらに発展させることにより, 完全な立体彫 刻物というよりは, カメオやインタリオのような擬似三 次元的彫刻物の制作も可能となると考えられる.

\section{4. おわりに}

本研究では, 新しい芸術的加工法として, 小片分割加 工法一Segmented Pixel Drawing法(SPD法)の加工システム を構築し, 画像を元にいくつかの異なった趣を有する芸 術的加工物を制作した.SPD法は加工範囲を小片に分割 し，小片ごとに異なった制御パラメータにて加工を行な うことにより, 各小片にそれぞれ異なった視覚効果と階 調を作成表現することが可能であることが実験的に明ら かになった。

今回の実験では, 加工対象物として透明アクリル部材 を使用したが，レーザーを照射することによって照射点 に視覚的変化の現れる部材であれば同様の加工が期待で きる，例えば，黒アルマイトを施したアルミ材の場合 は，レーザー照射によってアルマイト膜のみが蒸散し， その部分のみアルミ材の光沢が表れるため, 本実験と同 じような効果を得ることができると考えられる。

\section{謝 辞}

本研究を進めるうえで, SPD加工装置の構築と実験に協 力をいただいた, 工学研究科情報システム学専攻博士前 期課程の戎谷一氏, 岩本正志氏, 藤原広和氏に感謝致し ます。

\section{参考文献}

1) K. Bondelie: Laser Focus World, Aug. (1996) 95.

2) G. Ogura, J. Angell, and D. Wall: Laser Focus World, Jun. (1998) 117.

3) 永井治彦：レーザー研究 28 (2000) 2.

4) 城戸 基, 浜田 直也, 杉橋 敦史, 山本博之, 小原昌弘, 西林茂, 南田勝宏, 菊間 敏夫：レーザー研究 29 （2001） 318

5) 佐藤行雄, 西前順一, 岩田明彦, 竹野祥瑞, 福島司, 金岡優：レーザー研究 28 (2000) 19.

6) 的場修, 志村努, 黒田和男：レーザー研究 26 (1998) 144.

7) 林健一: レーザー研究 28 (2000) 40.

8) S. Kawata, H. Sun, T. Tanaka, and K. Takada: Nature 412 (2001) 697.

9）窪田 恵一：レーザー研究 28 (2000) 3.

10) N. Sakurada, Y. Ishii, H. Ebisutani, K. Watanabe, and Y. Kubota: Proceedings of SPIE, Osaka, November, 1999, Vol. 3887, p. 349.

11) H. Ebisutani, N. Sakurada, Y. Ishii, K. Watanabe, and Y. Kubota: Proceedings of SPIE, Florence, September, 2000, Vol. 4184, p. 575

12）渡辺一弘：レーザー研究 21 (1993) 1245.

13) Y. Ishii, N. Sakurada, T. Sugimori, K. Watanabe, Y. Kubota, and K. Nagano: CDROM proceedings of the 8th International Symposium on Flow Visualization, Sorrento, September, 1998, No. 249.

14) N. Sakurada, Y. Ishii, K. Watanabe, and Y. Kubota: J. Visualization 4 (2001) No. 4, 349.

15) N. Sakurada, Y. Ishii, H. Ebisutani, K. Watanabe, and Y. Kubota: CDROM proceedings of the 9th International Symposium on Flow Visualization, Edinburgh, August (2000) No. 261.

16) N. Sakurada, M. Iwamoto, H. Ebisutani, Y. Ishii, K. Watanabe, and Y. Kubota: Proceedings of SPIE, Florence, September 4184 (2000) p. 607. 